$$
\text { portolis of }
$$

laminest Americans

siv

HRISTOPHER WREN 


as a-mendeded Have $30-1521$.

CHRISTOPHER WREN PLYMOUTH. PA.

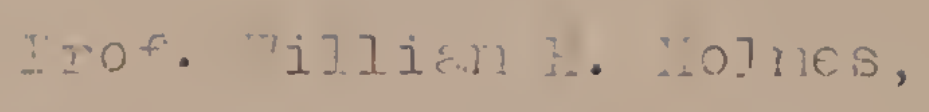

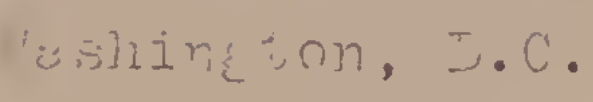

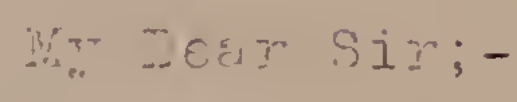

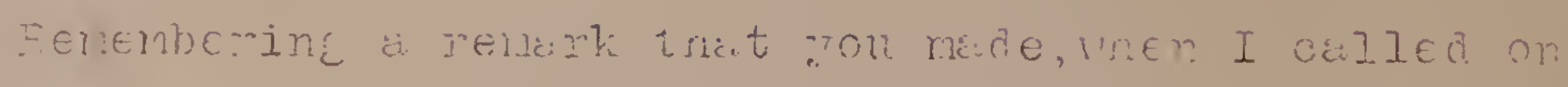

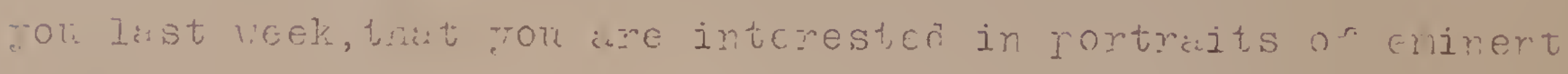

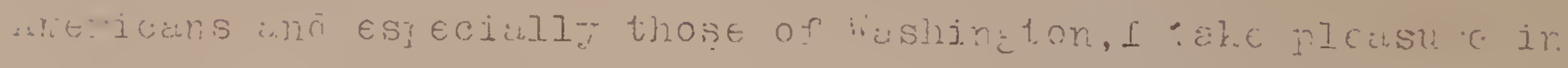

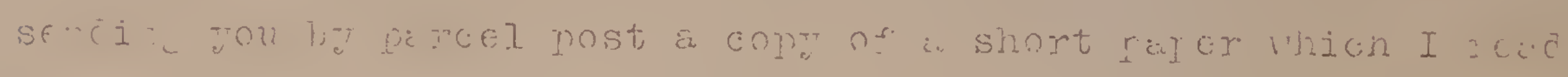

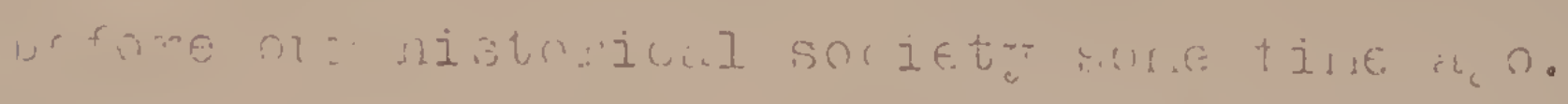

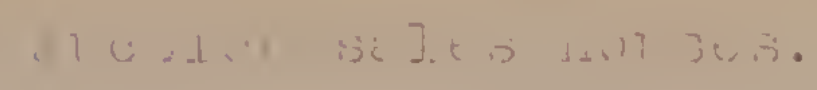

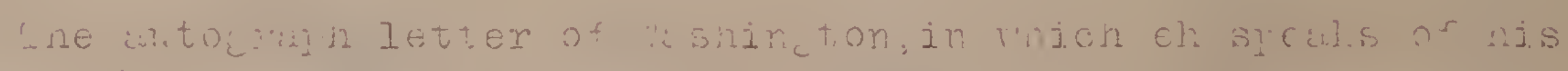

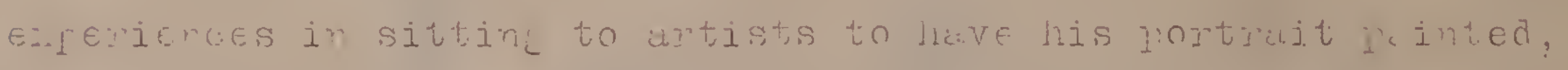

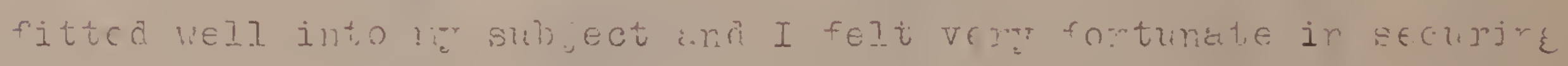
it.

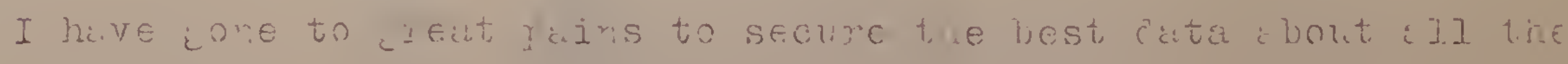

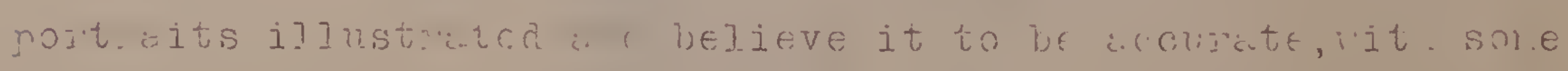

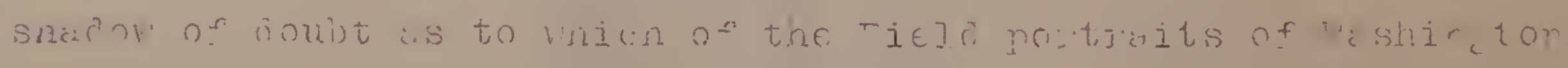

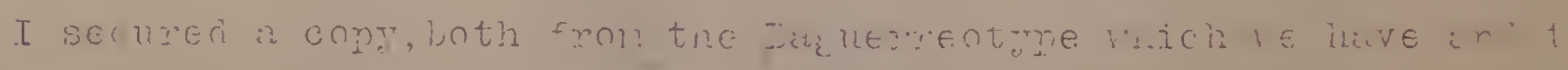

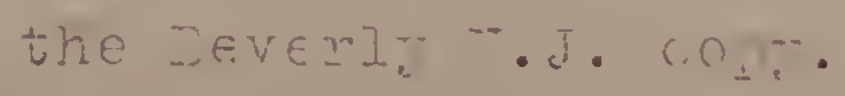

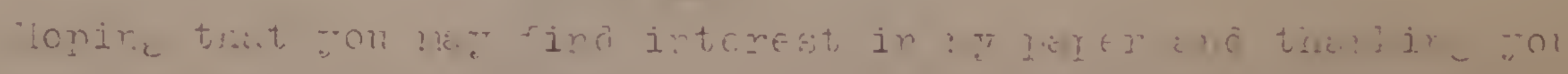

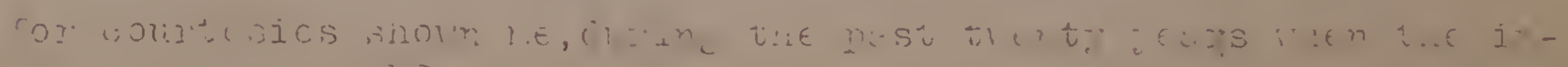
ins

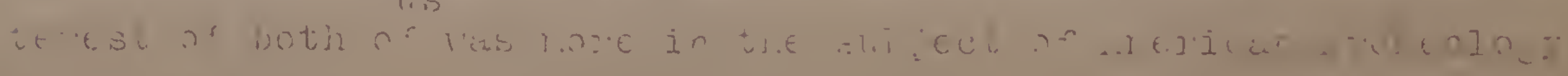

1 - (i ni) 
3

6

$i$

8

7 
Comprimecto of the author Grioposhod) Jrene 1921 



$$
-
$$




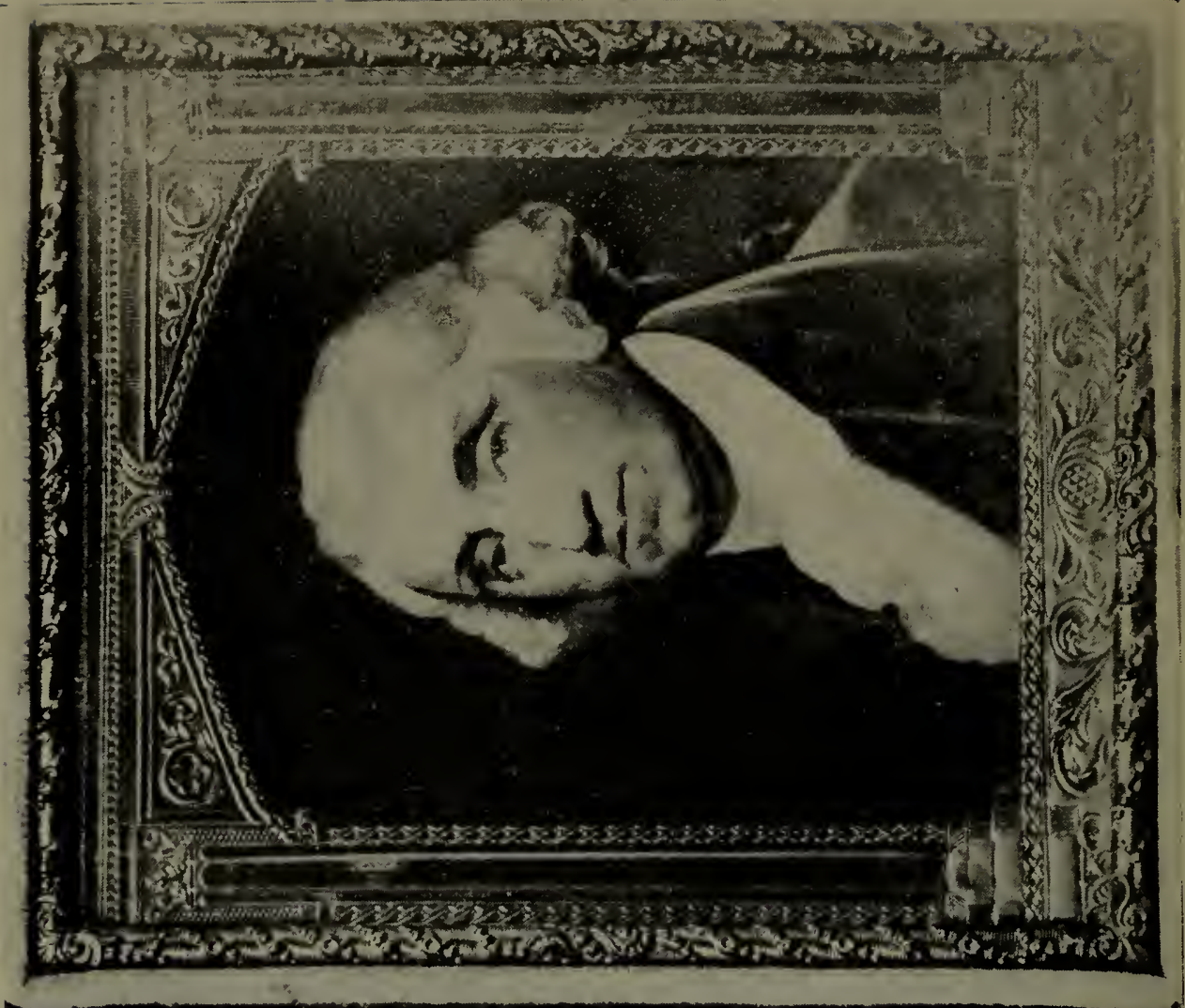

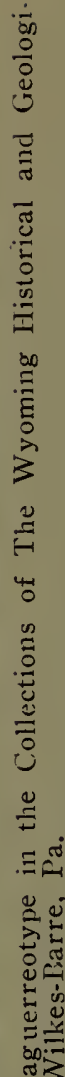

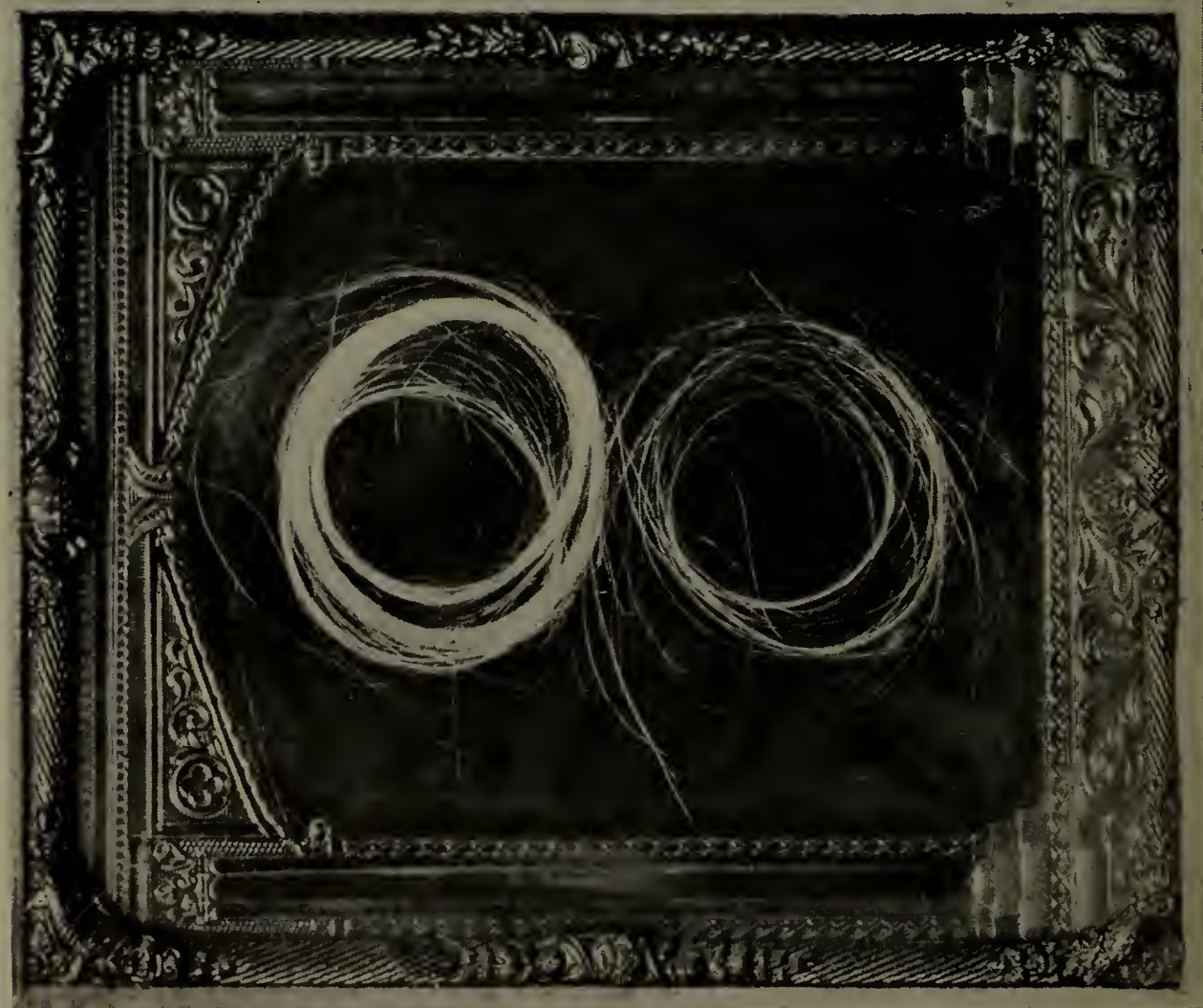

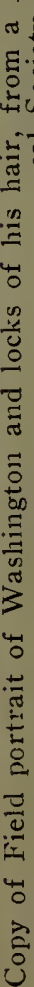




\title{
Portraits
}

\section{of Eminent Americans}

\author{
Which are Rare and Scarce.
}

By

\section{CHRISTOPHER WREN,}

Librarian,

WYOMING HISTORICAL AND GEOLOGICAL SOCIETY, WILKES-BARRE, PA.

\section{Reprinted from the Proceedines and Collectlons of the} Soclety, Vol. XVII.

THE E. B. YORDY CO., PRINTERS, WILKES-BARRE, PA.

1920.

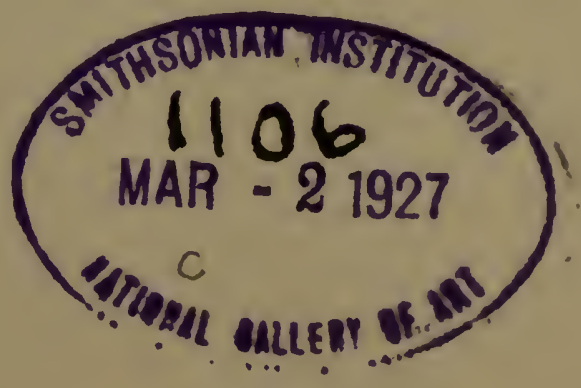



PORTRAITS OF EMINENT AMERICANS.

WHICH ARE RARE AND SCARCE.

By Christopher Wren, Librarian.

What constitutes the State?

Not high raised battlement or labored mounds,

Thick wall or moated gate:

Not cities proud with spires and turrets crowned,

Not bays and broad-armed ports

Where, laughing at the storm, rich navies ride;

Not starred and spangled courts,

Where low-browed baseness wafts perfume to pride.

No ;-Men, high-minded men,

With powers as far above dull brutes endued

In forest, brake, or den,

As brutes excel cold rocks and brambles rude-

Men who their duties know,

But know their rights, and knowing, dare maintain,

Prevent the long-aimed blow,

And crush the tyrant while they rend the chain:

These constitute the State.

\section{- Sir William Jones.}

Somewhat over fifty years ago Judge William Sterling Ross presented to The Wyoming Historical and Geological Society a collection antiques and relics of various kinds, which he had purchased from Mr. Harmon Chambers of Carbondale, Pa., and which became the nucleus around which the present museum of our Society has been gathered.

The collection consisted of geological specimens, Indian relics, ancient and modern coins, historical matter, and also a number of specimens from the old Peale Museum of Philadelphia and from the Dr. Abbott Museum of New York City, largely from Egypt. 
The detailed data which we have of this "Ross" (Chambers) collection being rather meagre, on learning that a son of Harmon Chambers lived at Beverly, New Jersey, correspondence was opened with him, with the object of obtaining such information as he might have about the collection owned by our Society. The writer paid a visit, also, to Beverly, and had an interview with Mr. Chambers, but as he anticipates writing a paper at some future time, devoted entirely to a description of this collection, only a single item, the Field Washington portrait, is taken up at this time.

While visiting Beverly attention was attracted to a portrait of George Washington which hung on the wall. Inquiry was made about this, which seemed to be an unfamiliar portrait of Washington; the information was given that it was copied from a miniature painted on ivory and presented to Thomas Meredith, a son of Samuel Meredith, first Treasurer of the United States, by a member of the Washington family.

A full description of this portrait is given in this paper, and it is illustrated as the Frontispiece Ia and also as Ib herein.

It is a very natural desire of the world to know as much as possible about eminent personages who have acted leading parts in its affairs, as statesmen, warriors, scientists, and in the other activities of life.

In the lapse of time all those who personally knew the leading actors of their generation pass from the scene, and, for a time, hearsay and tradition may give some idea as to what the characteristics of the individuals were, but eventually such data becomes more and more contradictory and unreliable.

Final judgments and opinions about eminent personages who have lived in times past are finally formed from two principal sources; either from written biographies of them or from good portraits. 


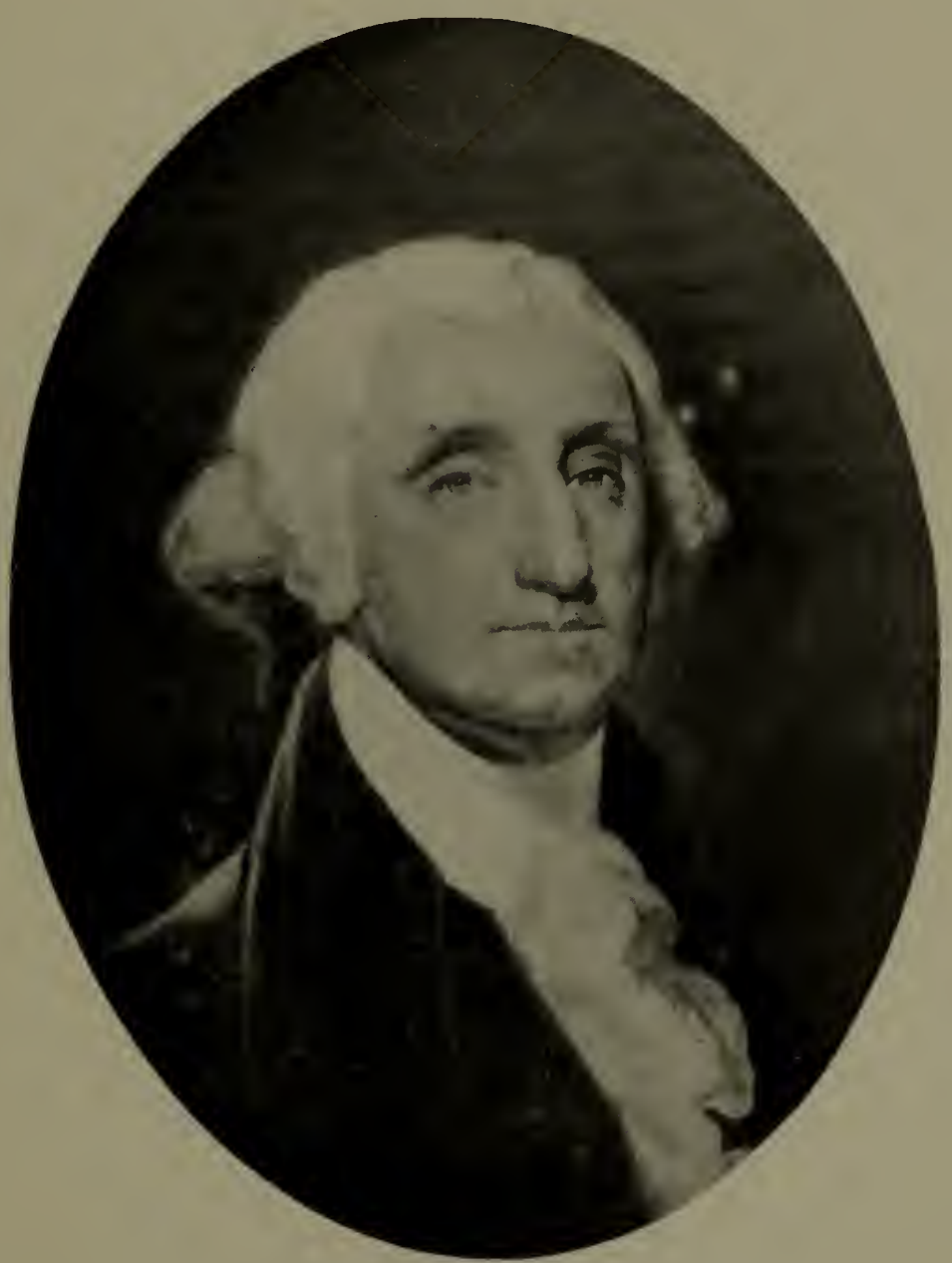

Copy of Field portrait of Washington, made from a life size colored photograph, in possession of Mr. Luther II. Chambers, Beverly, N. J. 

It has been said that biographies are very often written by admirers or friends, who, because of friendly partiality, give too flattering an account of the person about whom they are writing, or by persons who are unfriendly to their subject, and thus are hypercritical and fault-finding and lay too great an emphasis on the weaknesses and shortcomings of the personality they are describing.

A true likeness of the human face, also, generally gives a pretty fair index to the character of the person whom it represents, for do what we may we cannot prevent our personality from showing to a considerable degree in our countenances. Time and the experiences of our lives leave somewhat of their marks on our faces.

Beauty is not the standard on which we base our judgments, for there are plain featured people in whom we feel safe in placing trust, and other people whose beauty we cannot help appreciating and admiring, and yet we may not have the same sure confidence in them.

Before the discovery and practice of photography, portraits were made by hand painting, either in color with oil pigments or in plain black and white drawings or engravings. The truthfulness to nature of such portraiture depended on the extent to which the artist succeeded in catching those indefinite and indescribable features in their subject's face which express character and individuality. The artist must have not only the faculty of seeing these features in his subject, but also the technical skill to reproduce them on his canvas.

The originals of the portraits which are illustrated in this paper were very largely made before photography came into use, any exceptions having been produced after the Daguerreotype or Ambrotype came in vogue.

So far as we know none of the portraits herein described are widely known or have been much illustrated, while some of them seem to be shown in this way for the first time; and it is altogether likely that they will obtain a wider publicity 
in our volume than they have heretofore received. Such rare copies of them as may have been preserved are doubtless in the hands of private owners and are unknown to the general public.

All the portraits illustrated, being those of personages who were of national and international historical prominence, they naturally fit well into the historical department of our Society, and the best care has been taken to secure as complete and accurate data about them as possible.

\section{FRONTISPIECE. (Ib.)}

Portrait of George Washington and Locks of His Hair.

Among the very rare relics in our society's collections is this daguerreotype (or ambrotype) of Washington and his hair, illustrated as the frontispiece of this volume. Neither of the specimens of his hair was originally associated with the portrait, but they were presented to the society by Mr. Sharpe Delany Lewis, with this memorandum made by himself :

"Enclosed are two locks of Gen. Washington's hair, taken from some relics which were in the Delany family in Philadelphia, and in possession of Mrs. Josiah Lewis many years previous to her death. The hair was in two parcels labelled, and no doubt cut from the head at different times, at the house of Sharp Delany, at which he was a frequent visitor during the sitting of Congress in Philadelphia."

Note.-Mr. Sharpe D. Lewis, the donor, is a grandson of the Mr. S. Delany above referred to.

Signed: "C. F. I."

(Dr. Charles F. Ingham.)

Our present impression about the daguerreotype is that it came to our society as a part of the large collection which Judge William Sterling Ross bought at Carbondale about sixty years ago, as previously mentioned, and presented to the society.

This portrait seems to be a copy of the same original 


$$
-
$$

$$
\cdot
$$

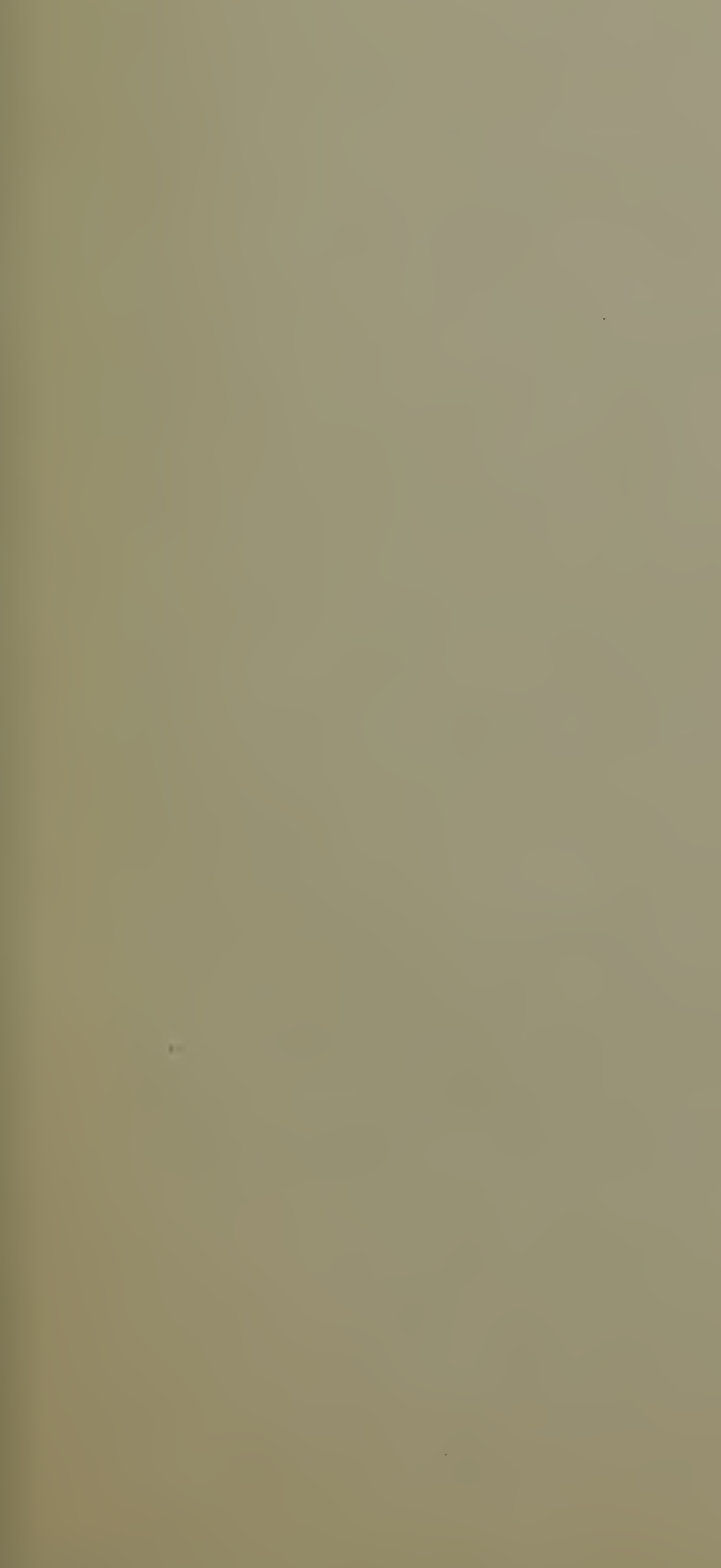




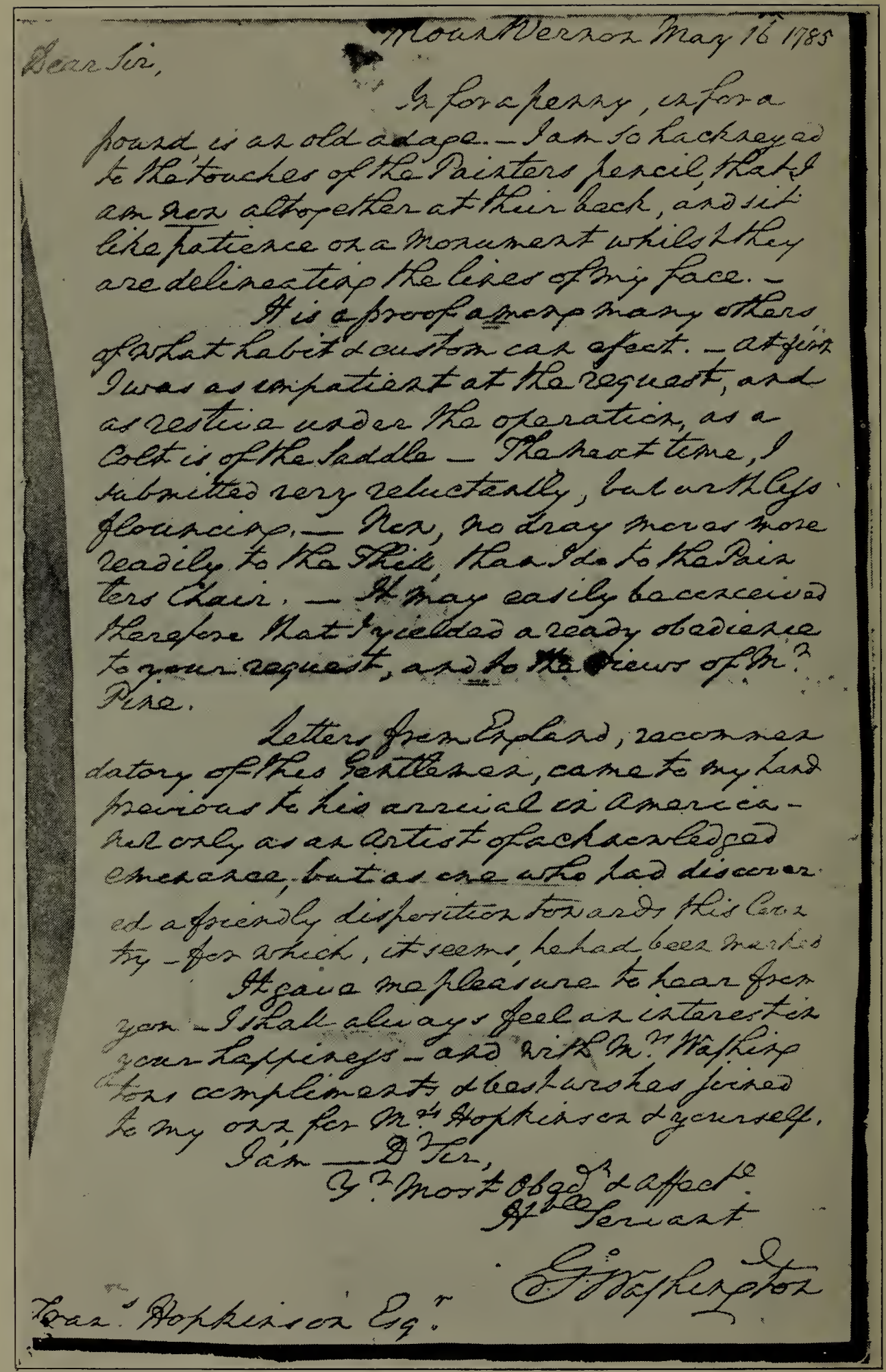

Autograph letter of George Washington, in possession of Mr. William Griffith, West Pittston, Pa., by whose courtesy it is here illustrated. 
miniature in oil as the one herein illustrated as Plate Ib, which was photographed from the colored picture now in the possession of Mr. Luther H. Chambers at Beverly, New Jersey, before mentioned.

Mr. Chambers told the writer that the original of his copy was a miniature painted on ivory and enclosed in a gold case, which he remembers having seen, at the time when it was owned by Samuel R. Meredith, grandson of the first U. S. Treasurer, and he was told that it was painted from life by an artist whose name he had forgotten.

At this point it seemed almost a hopeless chance of being able to trace the portrait further or to learn who the artist was that had painted it. After, however, writing a dozen or more letters of inquiry to persons who might be able to identify the portrait, the following letter was received from the Librarian of Congress :

\section{LIBRARY OF CONGRESS, WASHINGTON.}

"Manuscript Division.

October I, IgI9.

"DEAR SIR: In reply to your inquiry of September 29th, I find that the Washington miniature in question was painted by Robert Field, an English engraver and amateur painter, in the city of Washington, in the year I799. There seems to be no evidence available that it was painted from life, but the presumption is that it was painted from a miniature from life, which Field had previously executed.

"You will find a reproduction of the Field miniature on Plate XVI, of E. B. Johnston's 'Original Portraits of Washington,' Boston, I882, and an account of it on pages I I 5-II6. Field has apparently painted three known miniatures of Washington, and the one you inquire about appears to be the counterpart of his second miniature, which was given by Martha Washington to Tobias Lear, immediately after the General's death. This counterpart was made for Thomas Meredith, the son of Samuel Meredith, and remained in his possession until I853, when he gave it to Samuel $R$. Meredith, from whom it passed into the possession of 
Charles C. Moreau. Moreau had it in 1882 . As to its present whereabouts I have no further information.

"Very truly yours,

"(Signed) J. C. Fitzpatrick,

"Asst. Chief, Manuscript Division."

"Mr. Christopher Wren,

"Corresponding Secretary and Librarian

"Wyoming Historical and Geological Society.

"Wilkes-Barre, Pa."

The work of Miss Johnston's on "Original Portraits of Washington",* referred to in this letter, was consulted in the rooms of The Historical Society of Pennsylvania, Philadelphia, and the following information secured about the portrait and the artist who painted it:

\section{ROBERT FIELD.}

"This engraver and amateur painter executed three miniatures of Washington and one of his wife. Field is better known as an engraver, but his miniatures are excellent. He was on a visit to Mount Vernon in I798, and made his life studies there.

"The one taken at that time of Washington descended from Mrs. Lawrence Lewis to her grandson, Lawrence Lewis Conrad, Baltimore.

"This gentleman has three certificates establishing beyond question its claim to originality. Probably a more exquisite work will not be found in the entire collections of miniatures. It is on ivory and remains in the plain gold case, with a lock of Washington's hair plaited in the back.

"Dunlap and other writers of the day are not inclined to allow that these paintings were original, but there could be little doubt that Field would improve even by stealth, such opportunity as he enjoyed; and there is an individual touch and pose that strengthen this view. Their delicate finish and charming tints challenge the admiration of the most fastidious. They are marked 'R. F.'

"Field's second miniature, with the same initials, is owned by Mrs. Wilson Eyre, of Newport, R. I. It is not so well

*Original portraits of Washington, including statues, monuments and medals, by Elizabeth Bryant Johnston, Boston. James R. Osgood \& Company, I882.

To the memory of James Abram Garfield this volume is dedicated. 
preserved in color, or was not so highly toned, but in other respects it is the counterpart of the first.

"It was worn by Mrs. Washington in a locket, and immediately after her husband's death was presented by her to Col. Bear. It is set in a heavy plain gold case, and on the back is inserted a lock of Washington's hair. On the satin lining of the case is written in characters rather indistinct: 'Presented to T. Lear, by his friend, Mrs. Washington, I80I.'

"This miniature has been wrongly attributed to Archibald Robertson; but the drawing is decidedly the work of another pencil not possessing the vigor of the Scotch artist. In drawing, it is very like Stewart, with the exception of the mouth, which is better. It is in all respects a counterpart of the miniature known to have been painted by Field, owned by Mr. Charles C. Moreau, the enthusiastic collector of engraved heads of Washington.

"Therefore, it cannot be admitted that ' $R$. F.' stands for Romage fecit, nor for Robertson fecit, as thought by some. $\mathrm{Mr}$. Moreau has in his possession the following letter from a former owner, giving the history of the painting."

\section{"Mr. Moreau.}

$$
\text { “N. Y., Octo. 15, } 1858 .
$$

"Dr. SIR: This picture was painted by a Mr. Field, at Washington, in the year I799, for Thomas Meredith, Esq., who wished to take a likeness of the father of his country with him on his going abroad. It was pronounced by all the Washington family, and his immediate friends at the time it was taken, to be an admirable likeness; and Thomas Meredith himself knew Washington very well, having spent, by special invitation, four or five weeks with Washington at Mount Vernon, and also knew him well while Samuel Meredith (his father) was first Treasurer of the United States, and he (Thomas Meredith) also considered it the best likeness he had ever seen.

"This likeness has been through Europe, and to Calcutta, and Canton, and was in the Court of St. James exceedingly admired. This picture never was out of the possession of Thomas Meredith until it was handed by him to me in 1853 , as a present for valuable services rendered him.

"Yours respectfully, "(Signed) Samuel R. Meredith." 
Mr. Rembrandt Peale has a theory, which is given in this characteristic letter to Mr. Moreau, a part of which has been published by Mr. Lossing; and it is appropriate to introduce, though Mr. Lewis' certificate shows the venerable artist to be mistaken :

"Mr. Moreau.

"Philadelphia, Oct. 3, 1858.

"DEAR Sir: I thank you for the photograph of Washington from Field's miniature. It revives my recollection of the miniature which I saw last spring, which is a copy of Stewart's first portrait (not the one in the Athenaeum, Boston). Of course, this miniature was painted probably in I796. I have an impression that Mr. Field showed it to me in the year I798. Field was an Englishman, painted in a beautiful style, and commanded good prices. He went to Canada, studied theology (a little), was ordained, and had the grace to be made a Bishop, adorning the office with a fine portly figure and a pleasant countenance. When at Centreville, on the eastern shore of Maryland, we took a walk into the country after a rain. A wide puddle of water covered the road beyond the fence on both sides. I climbed the fence and walked round; but Mr. Field (fat and lazy), in good humor, paid a negro to carry him on his shoulders over the water. In the middle of it Field became so convulsed with laughter that he nearly shook himself off the old man's back. I never heard anything of him after he obtained his fat benefice.

"Will you do me the favor to write me how many prints of Washington you have?

"I wish to mention it in my lecture.

"Respectfully yours,

"REMBRANDT PEALE."

Much of what is here said may be thought irrevelant to the matter under consideration, but it is set down as indicating the blind leads and trails which may have to be followed out to get at the true and authentic history of things, while all the efforts put forth are in the end fully repaid by arriving at the truth of the matter sought after.

It may further be remarked that the manner in which the Meredith family of Philadelphia came to have friendly 


$$
\text { , }
$$




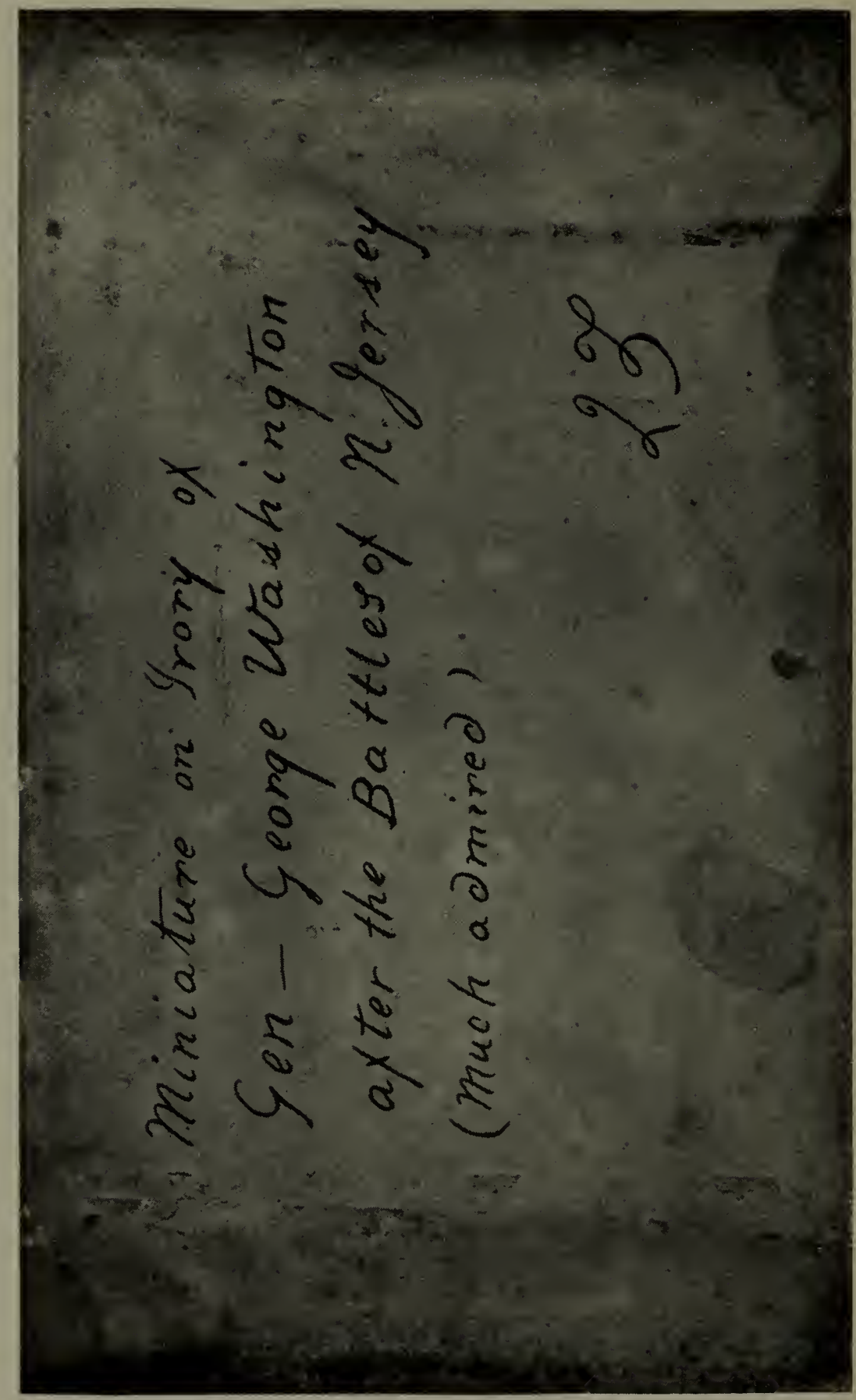

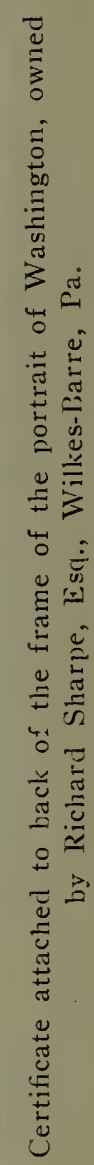


relations with the Washington family and to receive the General's portrait by Robert Field, may be explained by this foot note in Volume II of Watson's Annals of Philadelphia, which is quoted verbatim:

"I have heard one fact of the time, to be relied upon too; Reese Meredith, a merchant of Philadelphia, seeing Washington at a coffee house, was so pleased with his personal demeanor as a genteel stranger, that he invited him home to dine with him on fresh venison. It formed a lasting friendship, and caused afterwards, it is said, the appointment of another Meredith of the family to be the first Treasurer of the Union. As this acquaintance was formed without formal introduction, it long remained a grateful recollection in Meredith's family as a proof of his discernment. He was the father of the Treasurer."

Incidentally, it may be interesting to learn, in these days when we speak lightly of a billion dollars, that Samuel Meredith, the first Treasurer of the United States, received the handsome salary of two thousand dollars a year. The honor of serving the government, together with the social distinction which the office conferred, seem to have outweighed the salary received in those early days.

In conclusion, it may be said that, if the unfinished portrait of Washington, which is most popular and most often copied is a true likeness of the original, it seems to be a sound judgment to class this portrait by Field, also as an exceptionally good representation of how the first President of the United States really looked.

\section{By "J. T." (John Trumbull.)}

This beautiful oil portrait of George Washington is the property of Richard Sharpe, Esq., of Wilkes-Barre, Pa., by whose courtesy we are enabled to illustrate it for the first time, so far as we know. It is framed in a plain beveled 
gold gilt frame, three inches wide, the field on which the portrait is painted being $3 \frac{1}{2} \times 4$ inches.

The following is a description of the picture, etc.: Dark blue coat, black cockade hat, with rozette, buff coat collar, yellow epaulettes, white ruffled neck cloth, gray hair.

Just above the left shoulder, in the original painting, are the initials "J. T.," similar to those on the fac-simile certificate reproduced in this paper, but they do not show in the engraved copy.

\section{JOHN TRUMBULL.} Artist, $1756-1843$.

John Trumbull, the son of a Colonial Governor of Connecticut, was born at Lebanon in that State and died in New York city.

He graduated from Harvard and, having a taste for art, took up its study as a life profession.

He served with credit as a commissioned officer in the Revolutionary War under Washington and Generals Gates and Sullivan. He resigned from the army in I 777 to go to England and pursue his art studies under Benjamin West, to whom he had a letter of introduction from Benjamin Franklin.

He was, however, arrested and held in prison for eight months as a traitor to the British government because of his service in the Continental army. $\mathrm{He}$ was released from prison on condition that he leave the country, Benjamin West and J. S. Copley becoming his sureties.

After the close of the war, having spent several years in France and other parts of continental Europe, Trumbull returned to England and resumed his studies under West.

$\mathrm{He}$ was commissioned by the U. S. Congress to paint historical pictures for the government and is most widely known for his paintings of this kind; his Signing of the Declaration of Independence being one of his most popular works. Trumbull painted also the portraits of many of the prominent men of his time, among them being Washington, Hamilton and Jefferson. Some of his miniatures are said to excel his larger portraits, while his reputation is principally based on his historical paintings. 


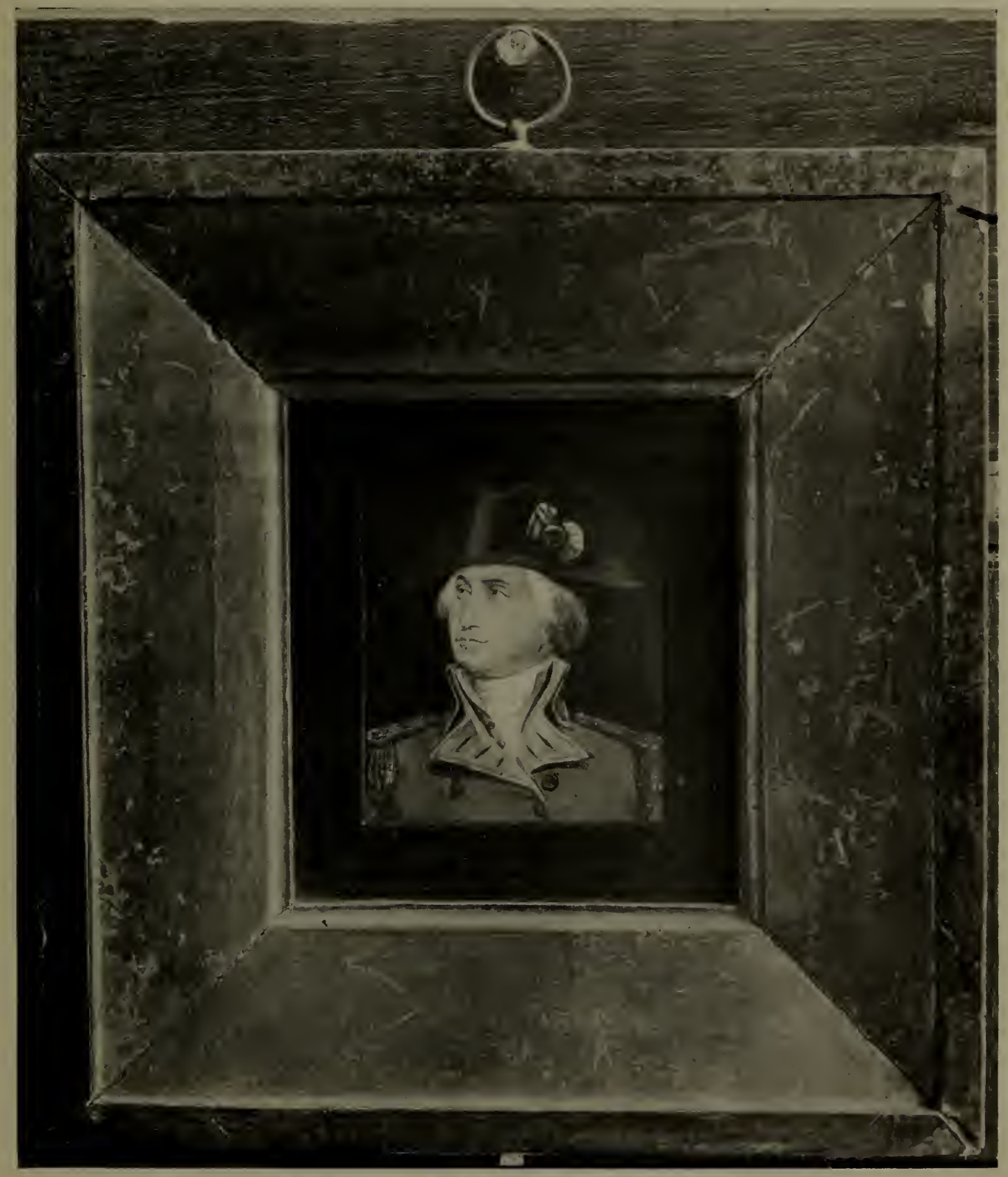

Portrait of George Washington by J. T. (John Trumbull), taken from the original painting owned by Richard Sharpe, Esq., Willies-Barre, l'a.

$$
\text { furtir bive }
$$






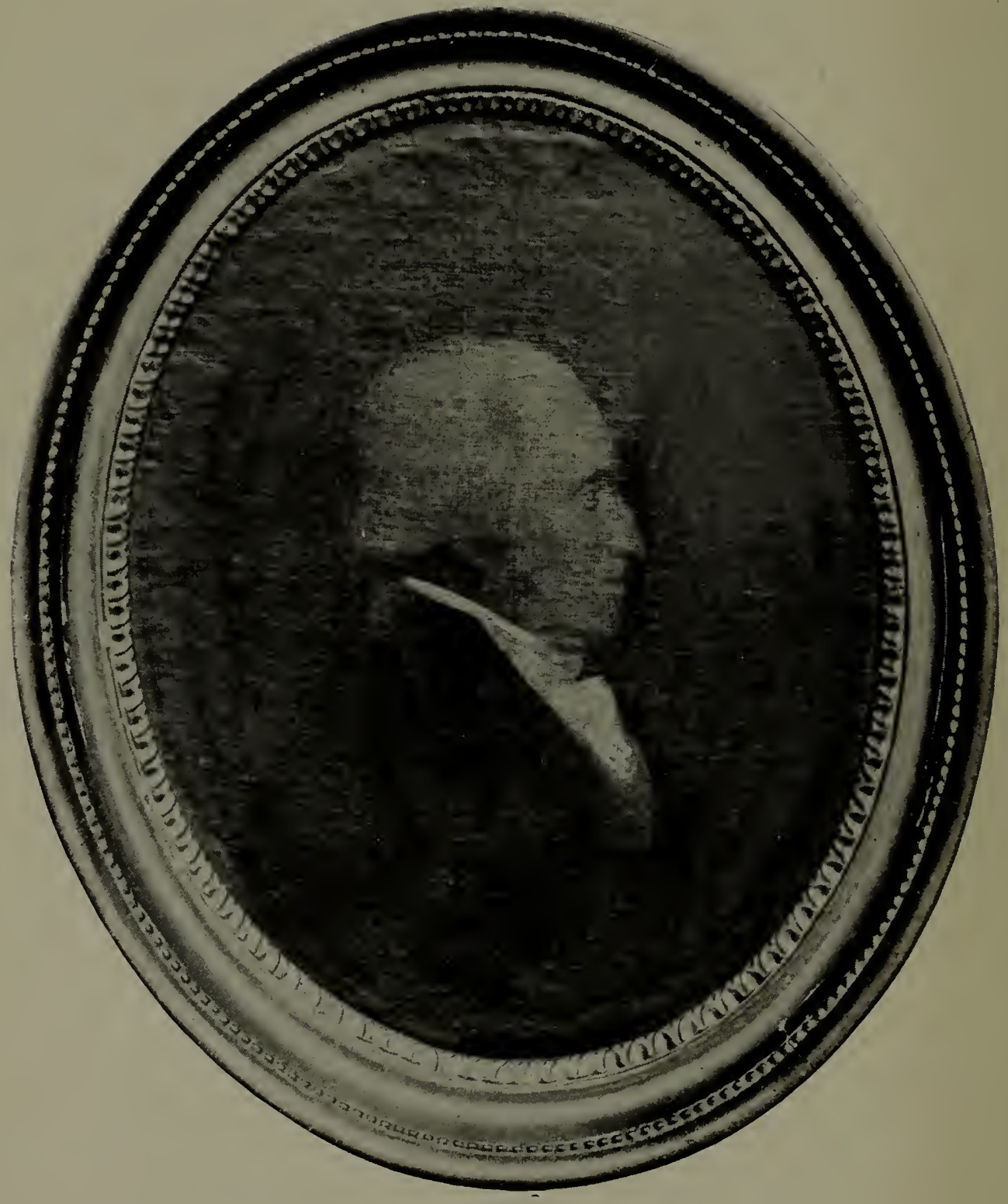

Portrait of Washington, by Cephas Thompson, copied from the original oil painting owned by Miss Frances G. Markham, Dorranceton, Pa. 
PORTRAIT OF WASHINGTON.

By Cephas Thompson.

Of this portrait of President Washington, the following history has been given to us: The portrait was painted by Cephas Thompson, and was owned by Cephas Giovanna Thompson, son of the painter, who himself became a celebrated painter and artist. He in turn left it to his daughter, who in turn willed it to Mrs. William Harris Markham. In course of time the portrait came into possession of her daughter, Miss Frances G. Markham of Dorranceton, Pa., and she has kindly consented to The Wyoming Historical Society now publishing it for the first time, as an unknown and well authenticated portrait of George Washington, the first President of the United States.

Cephas Thompson, who painted this portrait of Washington, was born in Middleborough, Massachusetts, in I775, and died in the same place in 1856 . He was one of the well known early American portrait painters.

Following the custom of the period, he spent each winter in the South, going from town to town painting portraits. Consequently his work is found in every city from Philadelphia to New Orleans.

The best known of his portraits are those of John Marshall, Stephen D. Decatur, Davis Ramsey of South Carolina, John Howard Payne, George Washington Parke Custis.

Custis was a pupil of Thompson's and probably because of this connection opportunity was given Thompson to paint the portrait of George Washington.

It is framed in the original gold gilt frame, the largest diameter of which is fifteen and one-half inches, the portrait being about one-half life size. As seen in the reproduction, the portrait bears evidence of its age.

The dress consists of a black coat, queue tied with a black ribbon (which shows faintly in the original, but has not been reproduced in the photograph from which the half-tone was made), white stock, frilled shirt and grey hair. 


\section{BENJAMIN FRANKLIN.}

After Joseph S. Duplessis.

Good portraits of Benjamin Franklin are extremely rare, which may give rise to speculations as to whether he was not adverse to having likenesses made of himself. It will be remembered that Franklin was a Quaker, and that the Society of Friends was opposed to pictures of all kinds. It has been suggested that their practice in this particular was because of a strict interpretation of the Commandment of Holy Writ against the making of any graven image or likeness.

We also bear in mind that when Benjamin West, having shown an unusual talent for art at a very early age, and it was proposed that he should take up that study as his life profession, it was strenuously opposed by the Friends' Meeting, and also by his own family; and it was only after long consideration that their rule in this matter was reluctantly relaxed in his case.

Having had business for a number of years with the Franklin Fire Insurance Company of Philadelphia, which used many portraits of Franklin on their business papers, the writer came to have a knowledge of about all of the likenesses of him, as that company used a number of them on its business stationery.

Almost without exception they seem to be mere casual sketches and not seriously considered portraits which had been made at sittings to professional artists. The inferior quality of these portraits can hardly be explained by a scarcity of portrait painters in America during his life, for there are a number of examples of good work done in this line during Franklin's lifetime; or, perhaps, because of the expense he failed to have his portrait painted, for we are led to believe that in money matters he resembled the canniness of the proverbial Scot.

The particular portrait of Franklin, which is illustrated in this paper, was copied from an engraved copy of the oil 


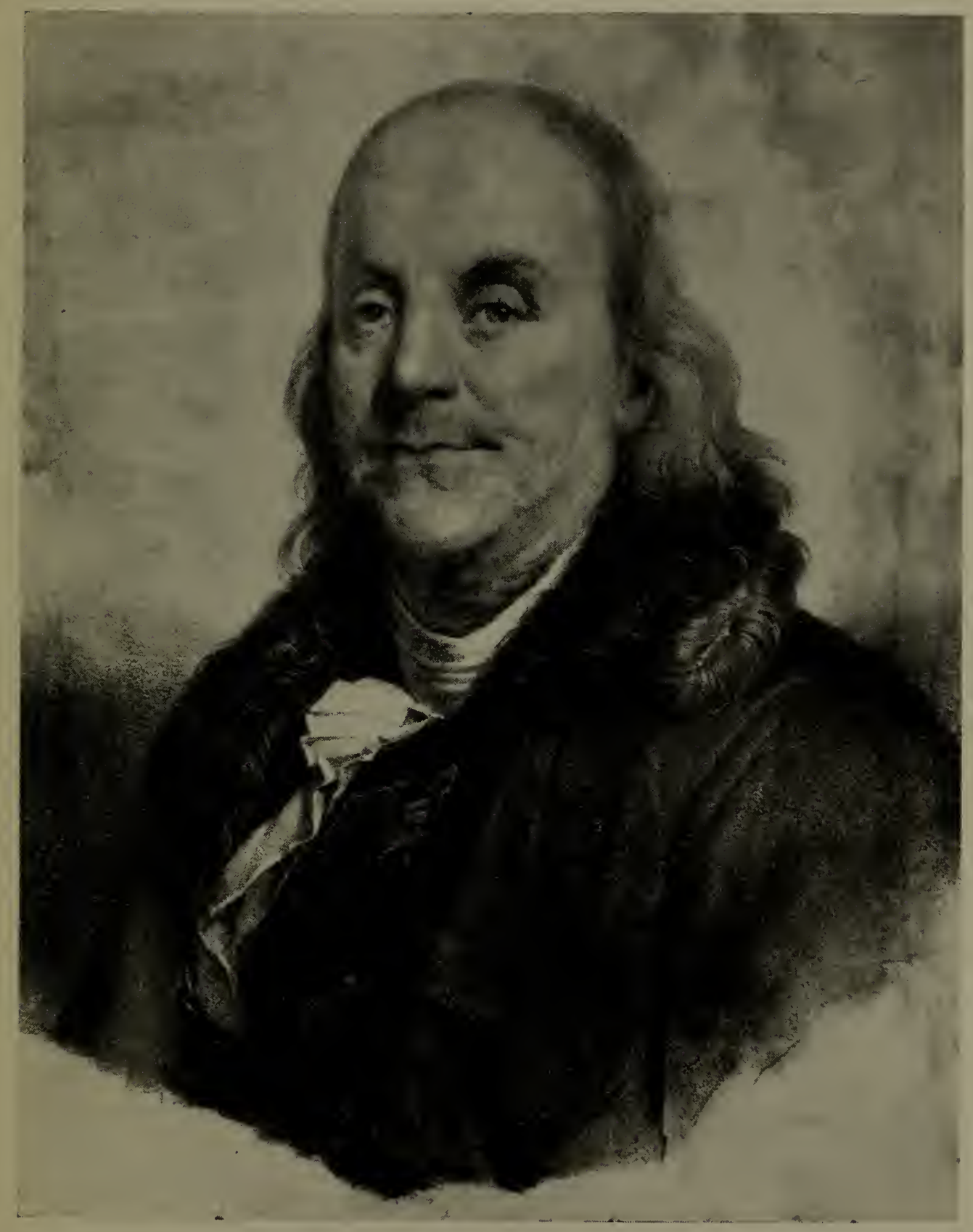

BENJAMIN FRINKLIN,

Peint d'apres nature pour la Famille.

Duplessis pinxit.

Exposé au Salon de 1779.

^. Maurin, Lith. 

portrait painted by Joseph Siffred Duplessis in Paris in the year 1778 , which was exhibited in the French Salon in 1779. This was during the time when Franklin, together with John Adams, Albert Gallatin and Silas Dean, were Commissioners from the American Colonies to the French Government, with the hope of securing their sympathy and assistance in the Revolutionary War. It is hardly necessary to say that their mission was successful, resulting in LaFayette, and other French officers, together with war-seasoned troops, and a part of the French Navy, coming to America and giving valuable aid to the struggling Colonies.

Franklin spent several years in France at this time, and was received with great consideration; in fact, was one of the "lions" of the day. It was conceded that his efforts as a diplomat in these matters had a large influence in producing a favorable result for our country. He was one of the most noted characters in Paris of the time and received the pseudonim of "the man of the hour". May it not be that seeing the fine portraits of his friends and the illustrious persons in Paris, he was led to consent to giving sittings to Duplessis for a portrait of himself, resulting in this most satisfying likeness that we have of him?

Franklin did not bring his portrait to America with him, which would seem to confirm the idea that he had no vanity about his own personal appearance, and but slight taste for pictures. The comments at the time on this particular Franklin portrait are said to have been very favorable by Americans who were visiting Paris, and by his acquaintances among the French people. The height and fullness of the brow indicate intellectuality; the kindly expression of the eyes a geniality of disposition and sense of humor, of which we have examples in the drollery of remarks attributed to him. At one time when the question of the friends of the Colonies standing firmly together was being discussed, he said: "We had better hang together, or we are likely to all hang separately;" and on another occasion, when attention 
had been directed to the half of a figure of the sun which ornamented the back of the chair of the presiding officer of the meeting, he likened it to the fortunes of the struggling Colonies, remarking that there was still some doubt as to whether it might typify a rising or a setting sun for them.

The mouth in the portrait indicates an amiable disposition, without weakness. It is a manly face, handsome, without prettiness, and, if it is not a true likeness of the man, we feel that he ought to have looked like this, judging him by his writings and his lifework. Yet with all his good and strong traits it would be a mistake to liken him closely to Nathaniel, who was "an Irealite, indeed, in whom there was no guile," for Franklin had his due share of worldly wisdom.

Joseph Siffred Duplessis was one of the most eminent artists of Paris of his.time, and painted portraits of the titled and wealthy people of France, including King Louis XVI.

\section{COMPOSITE FRANKLIN AND WASHINGTON STATUETTE. Staffordshire, England.}

In the Collection of The Wyoming Historical and Geological Society.

From the best obtainable information, this statuette was made in Staffordshire, England, about the beginning of the nineteenth century.

It was presented to the wife of Mr. George A. Edwards, a former member of the Wilkes-Barre Record staff, by her grandfather, who had bought it in Wales many years ago. Mrs. Edwards brought it to America.

That it is a composite of Franklin and Washington is plainly indicated by its different features.

The head is that of Franklin, while it is labeled General Washington. The head and face were doubtless taken from an engraving of the Duplessis portrait of Franklin, of which it is a fairly good copy, considering that it was made by a potter who was not a trained artist. The general figure seems also to be that of Franklin, as it is more retund than 



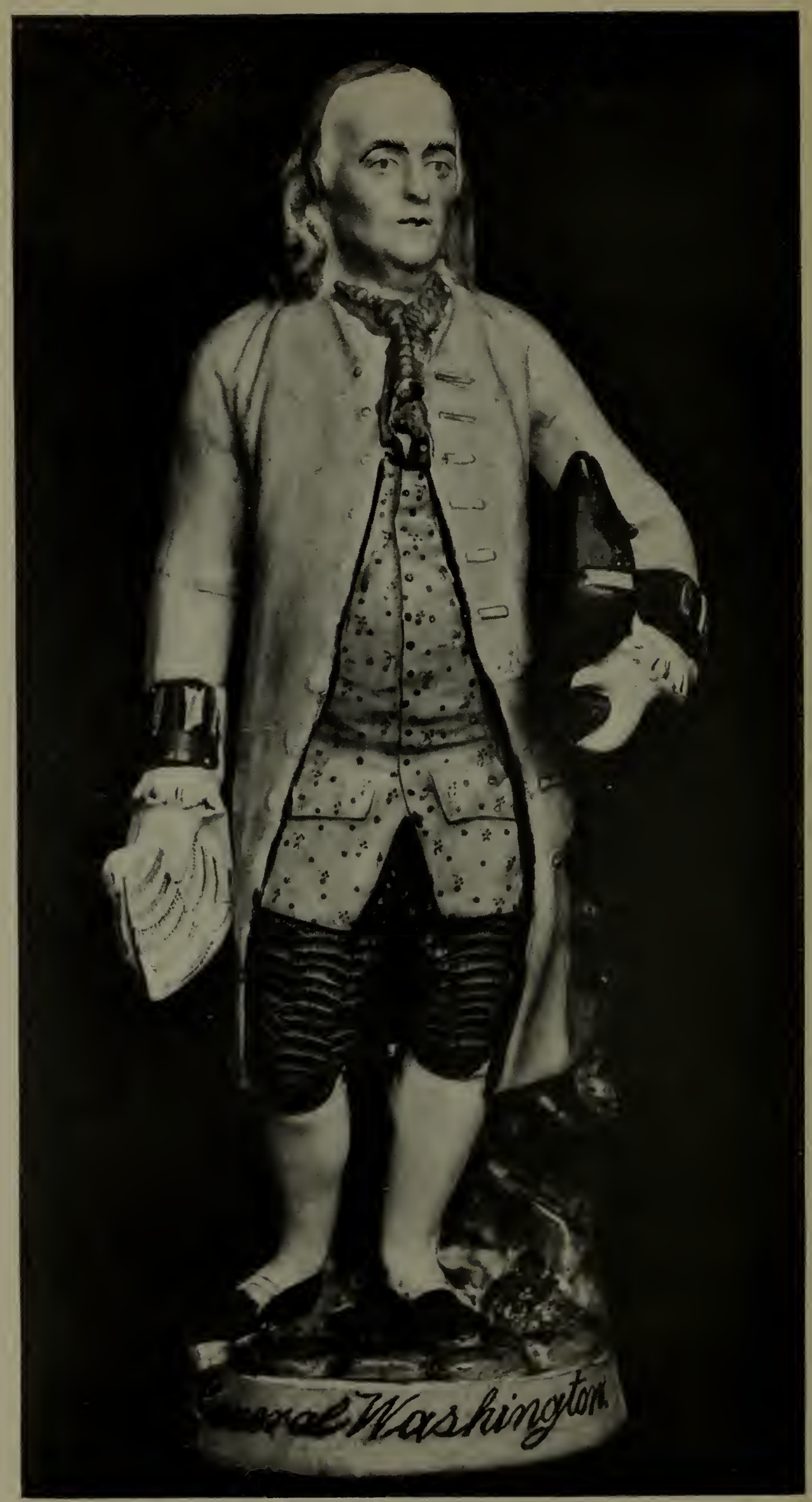

Composite Statuette of Renjamin Franklin and Ceorge Washington, made in Staffordshire, England, about 1800 ; in the Collections of

The Wyoming Historical and Geological Society.

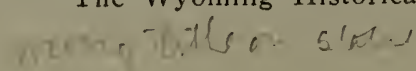


the figure of Washington, which we see represented in the statues and pictures of him.

In all other respects the potter seems to have had Washington, a military man, in mind, and followed his own ideas as to dress and other features.

He had probably heard of some of the addresses which Washington had made, and, perhaps, the scrool in the right hand of the figure is meant to represent "Washington's Farewell Address." Franklin was most eminent as a writer and diplomat, and if he had the art and graces of oratory we have heard but little of it.

The bright colored costume is also quite different from the plain clothes which Franklin, the Quaker, wore. The three-cornered hat suggests the military man, in which character Washington was most heard of in England at that early time.

So we may safely conclude that the Staffordshire potter who made this unique statuette of two of the most eminent Americans of their day and generation had but a hazy knowledge of the man or men whom he was representing.

The following is a description of the statuette: Height, fifteen ( I 5) inches; light blue coat, lined with red; red cuffs on coat sleeves and lace wrist cuffs; long yellow "sprigged" vest; red-barred short clothes; green neck cloth or tie, black "cocked" military hat in left hand; scroll representing an address or speech in right hand; white hose and low black slippers, with buckles.

It does not seem that Benjamin Franklin ever wore such a costume, and it is doubtful whether George Washington did either, although he followed the prevailing fashions more closely than Franklin did. The statuette is made of an opaque earthenware similar to the "Ironstone" china of the present day, and the colors were laid on under the glaze. 
ANDREW JACKSON.

By George P. A. Healy.

The daguerreotype of Andrew Jackson, from which the half-tone engraving here used was taken, was secured from Mr. Charles M. Johnston of Danville, Pa., about five years ago. He got it from Dr. Hedenburg, who at one time occupied some government position in Washington, D. C., and during that time made a collection of the portraits of notabilities in Washington. The Doctor afterwards removed to Danville, and, associated with his son-in-law, carried on the apothecary business at that place.

The original oil portrait from which the daguerreotype was taken was painted by George Peter Alexander Healy, an American artist of some note, born in Boston, Massachusetts in 1813 .

Healy visited Europe, and, on his return to America, under a commission from Louis Philippi, king of the French people, painted the portraits of a number of eminent Americans, among them that of Andrew Jackson, of whom he painted two, one of which was in The Hermitage, Nashville, Tennessee; the other hung on the walls of The Louvre, Paris, France.

After the Civil War The Hermitage was dimantled of all its furnishings by the relatives of Jackson.

About thirty years ago "The Ladies' Hermitage Association" was chartered by the State of Tennessee, which conveyed The Hermitage property to them and they have repaired the building to its former condition and are gathering the furniture and other belongings of Jackson, and replacing them in their old home as fast as circumstances permit. So far as known, the Healy portrait has not yet been returned to its old home in The Hermitage.

In looking over a catalogue of the items which have been returned to The Hermitage, several items appear which indicate that the Jackson family had somewhat intimate 


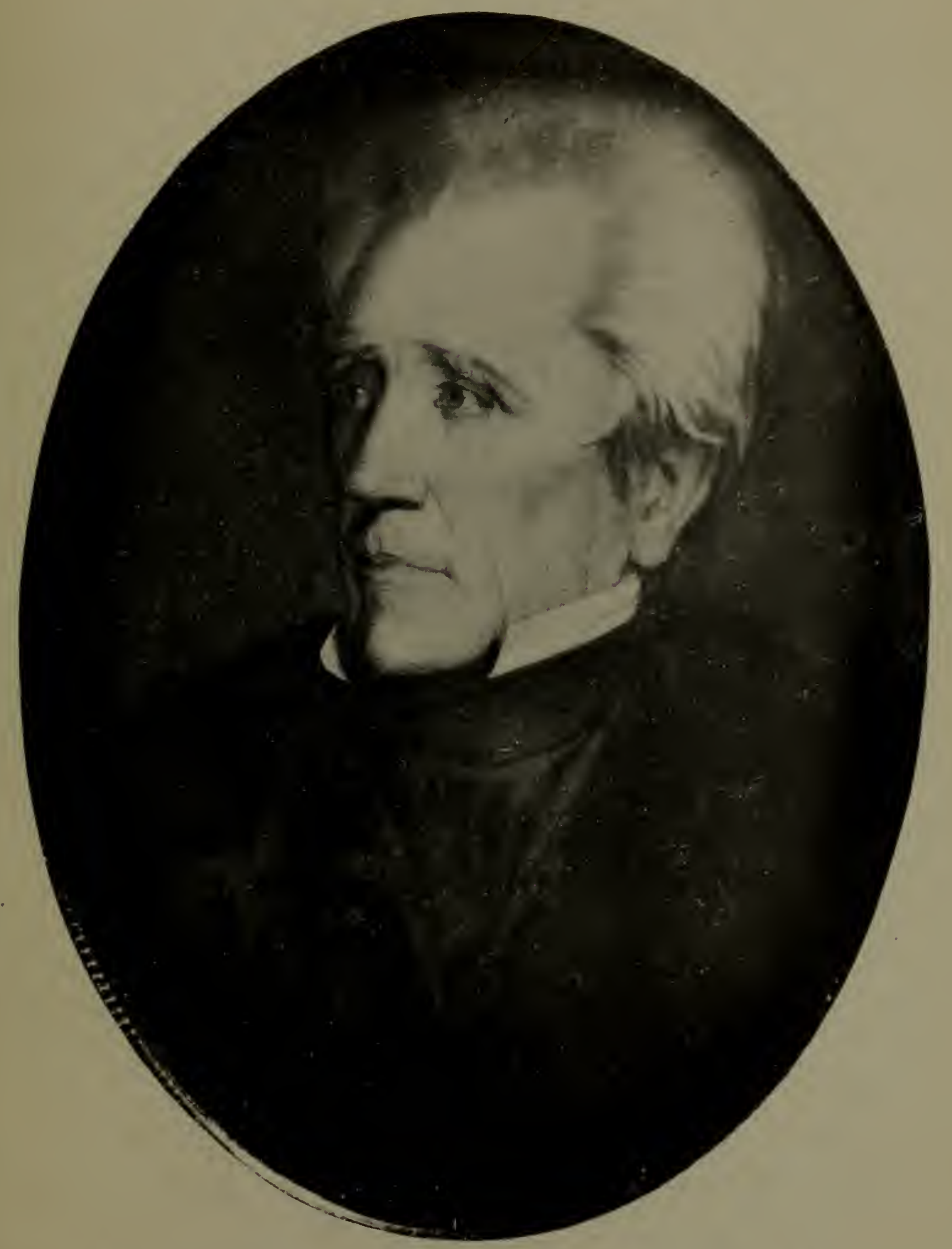

Andrew Jackson, copiel from a Jaguerreotype, owned by Christopher Wren, Librarian of The Wyoming Ilistorical and Geological Society. 
relations with families in our own State, which it may not be out of place to mention at this place.

Andrew Jackson's adopted son, Andrew (D.) Jackson, Jr., married a Miss Sarah Yorke of Philadelphia, and lived at The Hermitage, "where all her children were born, and the family were the solace and comfort of General Jackson's declining years."

Item 5, is a portrait of "John Meredith Read, Chief Justice of Pennsylvania, a friend of General Jackson." It is a curious coincidence that just at the time when the Field portrait of Washington becomes a part of this paper, the name of Meredith should appear a second time incidentally in connection with this description of a portrait of General Jackson and the furnishings of The Hermitage, Jackson's home. Martha Meredith, daughter of Samuel Meredith first Treasurer of the United States, was a sister of the Thomas Meredith to whom the Field portrait of Washington was presented, and she was the grandmother of John Meredith Read, Chief Justice of Pennsylvania before mentioned.

Item 26 is a "portrait by Earl of General Jackson on "Sam Patch," a magnificent white horse, presented to him in I833 by the citizens of Pennsylvania. General Jackson rode this horse in a grand civic and military parade given in his honor in Philadelphia, after which it was sent to Nashville and died during the Civil War. A Federal soldier whom General George H. Thomas had placed on guard, fired a military salute over the grave.

In the year I9I3 the old soldier who had fired this salute paid a visit to The Hermitage and pointed out the spot where Sam Patch was buried, which had been lost sight of, and the ladies intend to place a marker over the grave.

S. G. Heiskel, Esq., of Knoxville, Tenn., who has written a biography of Andrew Jackson, on receiving a copy of the daguerreotype illustrated in this paper, which was sent 
on request, expressed the opinion that it is a copy of one of the best portraits of the President extant.

It may also be of interest to mention that while the Northern army was in possession of The Hermitage during the Civil War a guard was placed over the property by order of General George H. Thomas, and no acts of vandalism or destruction were practiced by the soldiery on the estate.

$$
\text { "IF." }
$$

If you can keep your head when all about you Are losing theirs and blaming it on you,

If you can trust yourself when all men doubt you, But make allowance for their doubting, too; If you can wait and not be tired by waiting, Or being lied about, don't deal in lies, Or being hated don't give way to hating, And yet not look too good, nor talk too wise;

If you can talk with crowds and keep your virtue, Or walk with kings-nor lose the common touch, If neither foes nor loving friends can hurt you If all men count with you, but none too much; If you can fill the unforgiving minute

With sixty second's worth of distance run, Yours is the Earth and everything that's in it, And-what is more-you'll be a MAN my son. 

-

I 
SMITHSONIAN INSTITUTION LIBRARIES

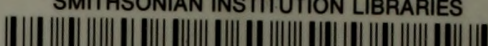

3 9088003049905 npg N7593.1.W94

Portraits of eminent Americans, 